\title{
Polarization but Not Pillarization Catholicism and Cultural Change in Post-Transformation Poland
}

\author{
Wojciech Sadlon
}

Citation: Sadlon, Wojciech. 2021

Polarization but Not Pillarization

Catholicism and Cultural Change in Post-Transformation Poland. Religions 12: 457. https://doi.org/10.3390/ rel12070457

Academic Editors: Tobias Köllner and Boris K. Knorre

Received: 9 April 2021

Accepted: 16 June 2021

Published: 22 June 2021

Publisher's Note: MDPI stays neutral with regard to jurisdictional claims in published maps and institutional affiliations.

Institute for Catholic Church Statistics, Cardinal Stefan Wyszyński University, 01-815 Warsaw, Poland; w.sadlon@iskk.pl

\begin{abstract}
The modern Polish cultural system emerges through the interplay between social structure and agency, which represent different properties and powers or, more precisely, 'independent properties, capable of exerting autonomous influences.' I argue that Polish Catholicism entered the transformation process to some extent as an agential force which shaped progressive social change and delivered 'energy' for the transformation of Polish society. However, the process of transformation has changed the public position of the Catholic Church as it is no longer an actor within a dominating social movement that thrived in the quest for freedom and human rights. Catholicism that has played a role in shaping social conflicts, still represents to some degree 'a public good'. That is why, despite strong political polarization in Poland, there is no context for 'pillarization' within Polish society. The situation of Catholicism in the modern Polish social configuration should be described using the category of 'polarization' rather than 'pillarization'. My study of Polish Catholicism confirms that social polarization in Poland is not a bottom-up process but rather, is driven from the top down as a cultural process.
\end{abstract}

Keywords: Catholicism; polarization; pillarization; transformation

\section{Introduction}

Sociology in Poland has developed a 'dualistic' model within studies of religion (Borowik 2002, pp. 85-86) encompassing two types of scholars, those who represented official Communist scholarly institutions and those who were affiliated with Catholic academia. Marxist approaches to religion affected the sociological study of religion in Poland in terms of theory and were the reference point for both scholars oriented towards Marxism and those attached to the Christian tradition who concentrated on 'questioning Marxist theses on the function of religion on society and the increasing secularisation in Poland' (Zielińska 2011, p. 81; Borowski 1985). Both groups of sociologists were affected by Marxist approaches to religion: those supported by the state-in a direct way, and the second group, those affiliated with Catholic academia - in an indirect way. This distinction, which profoundly influenced the sociology of religion in Poland, resulted from the differing ideological and normative perspectives of the scholars and their different attitudes towards the role of religion in Polish society (Borowik 2002). However, the distinction resulted also from different theoretical approaches to religion as such. On the Marxist side, studies in the sociology of religion tended to focus on the embeddedness of religion in social structures and on religious institutions as a manifestation of power. Whereas Catholic-based sociology of religion studies, apart from the passivist oriented Lublin-Warsaw school (Jewdokimow and Wojciech 2020), tried to highlight agential aspects of religion (Majka 1980; Adamski 1986; Dyczewski 1980). Until today, this dualism could be said to orient sociological approaches to religion among Polish scholars. The younger generation focus either on the role of Polish Catholicism in terms of power and hegemony (Zielińska 2018; Leszczyńska 2016; Grzymała-Busse 2015; Zubrzycki 2006) or on aspects of religious agency in society and culture (Wódka 2017; Rojek 2011, 2016; Sadlon 2014, 2021). Others in the special issue 
such as Ryszard Bobrowicz \& Mathias Nowak and Stella Grotowska are also looking at the Polish case in their analysis.

This latter approach tries to study the link between religion, politics and patriotism by following the assumption that 'a culture is the language of a spiritual experience' (De Certeau 1966). It affirms that the specific historical configuration of the religious situation in Poland has resulted in the strong link between religious experience and culture (Sadlon 2020a). In Poland, a country faced with a lack of religious freedom and the political authoritarianism of occupying political forces in the 18th and 19th centuries, Catholicism came to focus on the modern vision of the individual and transcendent salvation as its dominating idea (Sadlon 2015). New religious movements in the 19th century tried to establish a fresh link between social engagement and individual spirituality by pointing out that social life should be transformed and developed by Christian values and norms (Rojek 2011). In this way 'Polish messianism', represented by the leading Polish romantic and national poets in the 19th century, tried to usher in God's Kingdom on earth. Thus, such Polish authors as Adam Mickiewicz, Zygmunt Krasiński and August Cieszkowski elaborated a Christian vision of society even before the official Catholic social teaching inaugurated by Pope Leo XIII in his encyclical 'Rerum Novarum' (Rojek 2016). These messianic ideas invited readers to become socially engaged or even fight for freedom but in accordance with Christian values. According to Pawel Rojek (2016) such a 'theology of the nation' has been found in Polish history, from Pawel Wlodkowic in the 15th century, to the Solidarity Movement at the end of the 20th century; it was developed by Pope John Paul II and has dominated modern 'Polish culture'.

Such an agential perspective explains why both the classical and neoliberal ways of thinking about 'civil society' can be applied to Polish history (Cohen and Arato 1994). Civil society as characterised by independence, freedom, self-organisation, and mobilisation exists at the interface of public and private realms, the common good and the individual. In such a perspective, civil society represents the sphere of values and freedom. In fact, Cohen and Arato (1994, p. 9) refer to the liberation movements of the twentieth century that were observed in Poland as representative of civil society. Moreover, Seligman claims that the idea of civil society revived in Poland when the working class began to oppose the Communist government in the 1970s (Seligmann 1992, p. 9). According to these scholars, the concept became popular due to its usefulness in describing the struggle against communism and military dictatorship. Gawin notes that Christian tradition influenced the emergence of idea of civil society (Gawin 2013, p. 370). What is more, there are many historical commonalities between the history of Polish independence and idea of liberty found in the French Revolution (Załęski 2012).

In this paper, I will highlight the impact of Polish Catholicism on Polish society in the public sphere. Catholicism for me is a socio-cultural system (Archer 1988) integrally related to the Catholic system of theological and anthropological ideas which represent a conceptual framework (Taylor 1989) or 'lifeworld' (Habermas [1981] 1987). Such a vision of Catholicism may imply the question on agential aspects of Catholicism, in other words, my vision of Catholicism is more agential than structural. I analyse the social configuration of Catholicism within contemporary Polish society and present the transformation of the social agency of Polish Catholicism within Polish society as a change from the 'public' or 'common good', to something of a much more factional and lateral nature. Cultural transformation in Poland, including the growing pluralism (Liedhagener 2018), affects the social role of Catholicism as a social actor and its potential social identities (Archer 2000, p. 260). I assume that the modern Polish cultural system emerges from the interplay between social structure and agency, which represent different properties and powers or, to express it more precisely, 'independent properties, capable of exerting autonomous influences' (Archer 1995, p. 6).

My study of Polish Catholicism is framed within two concepts: polarization and pillarization. I assume that pillarization (Herberg 1955; Kruijt and Goddijn 1962) is not only when 'a movement or group succeeds in mobilizing a large section of the population' 
(Hellemans 2020, p. 124), which I define as 'polarization', but it is also a structural characteristic of a society that manifests in 'a pervasive subculture and by setting up a vast interrelated network of organizations, resulting in a seemingly impenetrable and powerful bloc' (Hellemans 2020, p. 124). For me this means that pillarization is to some extent a result of mobilized polarization, consisting not only as an ideological constellation but also emerging from a vast network of organizations and institutions that provide systematic social services.

From such a perspective, Catholicism played an important role in post-war pillarization in Europe (Billiet and Dobbelaere 1976). My study of Catholicism also includes the theory of pillarization but in a rather 'soft' version that incorporates such categories as 'milieu' (Damberg 1997; Altermatt 1980) or even 'world' (Poulat 1986; Diamanti and Ceccarini 2007). Andrew Greeley has suggested that in the case of the United States the discourse on pillarization was much more sophisticated and included discussion of the Catholic contribution to the national community (Greeley 1962). My distinction between polarization and pillarization seems to fit the insights of Staf Hellemans (2020, p. 126), who argue that despite the fact that the category of pillarization still informs studies on religious configuration in the international perspective, in late modernity, societal segregation 'is less absolute than terms like "pillar", "world" or "sub-society" seem to suggest-the economy, science and technology were less affected and class divisions and types of occupation had a greater impact on daily life than the cultures of the blocs.'

\section{Catholicism: Between a Social Actor and a Public Institution}

Catholicism has actively participated in the national struggle for freedom and identity in Poland since the 1960s. The role of Catholicism in building up national identity and social capital could be compared to a Cinderella-like character, as, despite being banned from the public sphere, the religion was enacted publicly and revealed its role at critical moments in Polish history. In the process of political transformation, Catholicism has ceased to operate as 'Cinderella' and its role in the public sphere has changed (Sadlon 2020a).

The public role of Catholicism in Poland is embodied especially in two monumental personalities: Stefan Wyszyński and Karol Wojtyła, the future Pope John Paul II. Stefan Wyszyński successfully inaugurated a strong pastoral movement, the mobilization of Polish Catholics (the Great Novena), especially in rural parishes across the country, as the preparation for the celebrations of the Millennium of 'the Baptism of Poland' in 1966, the anniversary of the conversion and baptism of the first ruler of the Polish state, Mieszko 1 in 966. In doing so, he became the unquestionable leader of the Polish-nationalist emancipation movement in its opposition to Communism. Similarly, the role of the Polish Pope was not only religious. His election mobilized the social engagement of Catholics in Poland and, during the 1980s under the Communist regime, delivered a platform for a new public role for Catholicism, inspirating the rise of the Solidarity Movement.

The recent history of Poland seems to confirm Ronald Inglehart and Wayne Baker's description of the relationship between cultural and economic transformation: that 'the cultural change seems to be a path dependent' on economic transformation (Inglehart and Baker 2000). Intense Church and State relations have characterized the Polish political system since the 1960s (Schöpflin 1974). Before and during the period of the Solidarity Movement, Catholicism represented opposition to Communism and allied itself with the Polish nation. The independence of Polish Catholicism from the Communist state was much more evident than in the case of Hungary or Czechoslovakia. An important role was also played by the historical correlation between national and religious identity. The dynamic role of Catholicism in shaping social attitudes manifested in the emergence of vibrant Catholic youth movements (Michel 1988). Later, in the 1980s, the Church came to be seen as 'a national advisor' and in this way its authority was preserved and acknowledged by both the non-Catholic opposition and the Communist elites. According to a poll in 1984, nearly 63 percent of respondents stated that the most influential 'political personality' for the Polish state and nation was Cardinal Stefan Wyszyński (Michel 1988). 
The Catholic Church has played an important role in democratic transformations, not only in Poland, and represented the 'power' and motivation for liberation and democratization movements around the world (Eberts 1998). In the 1980s, the Catholic Church inspired more confidence among Poles than any other institution or organization (Hruby 1982). Before 1989, Catholic religious education was very limited, as the Church operated no more than eight schools. Nevertheless, religious education was offered at 'catechetical points' organized within parishes and private homes (at that time there were over ten thousand of these) (Żurek 1996, p. 7). This means that, although official religious education was banned from schools, as was the case in other socialist states (Köllner 2016), nevertheless, and in contrast to many other former socialist states, religious education enjoyed some privileges in Poland and was successfully achieved within parishes. However, the situation changed at the beginning of the 1990s; the democratic breakthrough opened up Catholicism to the new perspective of institutionalization.

Over the last three decades, the organizational structure of the Catholic Church in Poland had been growing rapidly. Since 1972, there were twenty-seven Diocesan units in Poland, including twenty-four Dioceses and three Apostolic administrations. In 1991, the Military Ordinariate was restored in Poland and in 1992, nearly 20 new Dioceses were recognized. In 2004, two new dioceses were created. Since 2004, the administrative structure of the Polish Catholic Church has consisted of fourty-five entities: fourty-one Roman Catholic Dioceses, the Military Ordinariate of Poland, and three Dioceses of the Greek Catholic Rite. The increase in the number of Dioceses in Poland is also reflected in the number of bishops. In 1974, there were 7057 parishes. By 1985, the number of parishes had risen to 8302. Recently (2019) the number of Catholic parishes was 10,381 (Sadlon and Luiza 2020). In 1980, there were 15,157 diocesan priests, by 2005 this figure had increased to 22,448 (a growth by 45 percent). Between 1990 and 2010 the number of priests increased by 4978 (a growth of 22 percent) (Witold and Wojciech 2011).

In 1991, on average, there were 4031 people in each parish, decreasing to 3282 in 2011 (Sadlon 2019, pp. 358-59). The process of institutionalization of Polish Catholicism during the last three decades is especially relevant for religious education. After 1989, the number of Catholic schools in Poland grew steadily and since then the situation of religious education has changed rapidly. In the 2010s, 58,000 pupils attended 540 Catholic schools (Jaron 2014, p. 232). In the 2010s, 36,000 public schools offered religious education, which accounted for 86 percent of all public schools in Poland, and the number of 'teachers of religion', as designated by the Catholic Church and employed in these public schools, amounted to 31,000. Since religious education began in public schools in 1990, declared participation in religious classes had been growing, from 81 percent in 1991 to 93 percent in 2010 (Grabowska and Gwiazda 2019, pp. 162-65). This process of institutionalization concerns other Catholic organizations, including charities. In the Communist period, the Church ran only 16 charity establishments. Since 1989, the Church developed an intense focus on charitable organizations. In 2014, there were over 800 Catholic organizations in Poland, who conducted 5000 varieties of charitable work with 2.9 million beneficiaries (Sadlon 2015).

\section{Catholicism as a 'Public Good' and a Symbolic Reference}

Since the process of political transformation in the 1980s, Catholicism has gained institutional status and an official place within Polish civil society. The legal status of Catholic organizations in the Third Republic of Poland is defined by the Law on Freedom of Conscience and Religious Liberty of 1989 (Dziennik Ustaw 1989) and Article 25 of the Polish Constitution, promulgated in 1997. These declare mutual 'respect for the autonomy and the mutual independence of each in its own sphere, as well as recognition for the principle of cooperation, for the individual and the common good'. To some extent, the legal position of the Church was confirmed in the democratic reforms. What is more, 'churches and other religious organizations shall have equal rights' (The Constitution of the Republic of Poland, Article 25). Catholic organizations are not subject to the Law on Associations 
as, in light of the enactment of the Law on Public Benefit and Volunteer Work of 24th April 2003, religious organizations are not regarded as non-governmental organizations, but are accorded equality in their conduct of public benefit activities. 'Public benefit activities may also be carried out by legal persons and organizational units operating under the provisions of the relations between the State and the Catholic Church in the Polish Republic, as well as by other churches if their statutory goals include carrying out public benefit' (Dziennik Ustaw 2003). In 1993, the Polish state and the Holy See signed an agreement (a so-called concordat) that was ratified by the Polish parliament in 1998.

Despite the fact that parish-based social capital is bonding rather than bridging, the Catholic Church represents the largest field of social capital at the local level in Poland (Sadlon 2014). In 2018, more than 65,000 informal parish-based organizations operated nationally and had 2.5 million members, that is, a huge number in comparison to the total number of all non-governmental third sector entities, that is, 100,000 registered entities (Polish Statistics 2020). Among the 1800 religious social institutions which provide public benefit, 96 percent of them are Catholic. Catholic organizations provide different public services especially in the fields of education, social protection and health care. As is pointed out by Piotr Sztompka: 'due to the long periods of foreign domination and oppression, the army and the Catholic Church, recognized as the embodiment and depositaries of national struggle and centres of national identity, have always been at the forefront of the list of most trusted institutions' (Sztompka 2007, p. 107). Social trust in Catholicism is primarily related to local relationships to the parish.

Some authors even claim that the groundwork for the Polish version of civil religion was prepared at the time of the transformation (Morawska 1984) and 'released' after 1989 into the public space. Catholicism was thereby transformed to some extent into Poland's civil religion (Zarzecki 2015). In other national contexts, Jose Casanova highlights the possibility of the Catholic Church playing a social role even in pluralized and differentiated societies (1994, pp. 92-113). Jay Demerath adopts the term 'cultural religion' to characterize religion in Poland (2000). According to him, the specific configuration of recent Polish history resulted in strong bonds between politics, represented by the Solidarity Movement, and the Catholic Church.

However, the link between religious identity and patriotism results from much earlier configurations. Catholicism has always been regarded as an element of Polishness. The expression 'Pole-Catholic' has been used in public discourse by representatives of both the Church and politicians. Roman Dmowski, a famous Polish politician and statesman, and co-founder of the political movement National Democracy, active from the second half of the 19th century, promoted a vision of a homogenous Polish-speaking and Roman Catholic-practicing nation. Ignacy Kłopotowski, a Polish Roman Catholic priest, and the founder of an order of Catholic nuns, began in 1905 to publish a series of newspapers known as 'Polak-Katolik' (Polish-Catholic). Catholicism became a criterion of national identity. 'To be Polish was to be Catholic; supporting the new Poland involved attending the old services' (Demerath 2000, p. 128), despite the fact that the link between patriotism and Catholicism goes back to the distant past (Koseła 2003).

Such claims seem justified in the sphere of 'cultural Catholicism'. The Catholic Church is the most important religious institution in Poland and affiliation to Catholicism is without doubt very common in Poland. According to the Polish census of 2011, which for the first time since the 1930s included a question on religious affiliation, the percentage of Catholics varied from 88.8 percent to 97.3 percent of the population (Gudaszewski 2015, p. 93 $)^{1}$. According to surveys over the last three decades, the level of Catholic affiliation in Poland clearly exceeds 90 percent and is relatively equal to the proportion of people who declare their belief in God. According to Polish statistics, in 2018, 91.9 percent declared belonging to the Roman Catholic Church (Bieńkunska and Piasecki 2020). In the last three decades, more than 90 percent of new-born children were baptized in the Catholic Church (Sadlon and Luiza 2020). About 3.5 percent declare attending Mass more than once a week, 46.5 percent once a week, 17.3 percent once or twice in month, 26.4 percent only on the 
occasion of holidays or less often, and 6.3 percent of the respondents never come to church. When asked about their relationship with their parish or other local religious community, 21.8 percent of respondents declared that they are 'strongly associated' with it, 44.1 percent 'rather related', 13.5 percent 'rather unrelated', and 13.6 percent 'completely unrelated'. The majority of Polish society declare praying at least occasionally. No more than eight percent declare not praying at all (Bieńkunska and Piasecki 2020).

Cultural Catholicism manifests in the link between family and religious traditions. Thus, commitment to family life is linked with religious commitment (Hipsz 2013, p. 7). Religious commitment in Poland to some extent reflects the tension between political modernization and 'familial conservatism' (Turner and Forlenza 2020). More than 90 percent of Poles declare themselves to be cultivating traditional family Christmas and Easter rituals (Feliksiak 2019). Surveys also show that there is still a deeply positive emotional attachment to the person of John Paul II in Polish society. In 2005, the anniversary of the death of John Paul II still motivated the creation of so-called 'occasional communities' (Sokołowski 2006; Dmochowska 2012, p. 99). In 2018, about 96 percent of Poles declared that 'generally Poles remember John Paul $\mathrm{II}^{\prime}$ and 71 percent that 'the majority of Poles know the teachings of John Paul II' (Boguszewski 2018). 'Family' and 'love' stay the most important values that also relate to the concept of 'religious marriage' (Ciecielag and Boryszewski 2017, pp. 123-29). Despite the fact that the practice of religious rituals is declining, the great majority still follow such Catholic traditions as fasting on Good Friday (2006 in 86 percent and 85 percent in 2018), confession at Easter (79 percent in 2006 and 67 percent in 2018), 'sprinkling the head with ashes' (Ash Wednesday) (71 percent in 2006 and 64 percent in 2018) and attending the Easter liturgy (65 percent in 2006 and 56 percent in 2018) (Głowacki 2018).

Moreover, there is some indication that core religious beliefs persist within Polish society. For example, statistics on belief in 'God', 'life after death' or 'heaven' are relatively constant over the last three decades. Even 'belief in hell' increased at one stage, as presented below (Table 1).

Table 1. Declared belief in God, life after death, heaven and hell, in Poland (1990-2017) (in percent).

\begin{tabular}{lcccc}
\hline \multicolumn{1}{c}{ Do You Believe in: } & $\mathbf{1 9 9 0}$ & $\mathbf{1 9 9 9}$ & $\mathbf{2 0 0 8}$ & $\mathbf{2 0 1 7}$ \\
\hline $\mathrm{N}$ & 982 & 1095 & 1071 & 1167 \\
\hline \multirow{2}{*}{ God } & \multicolumn{2}{c}{ In percent } & 96 & 94 \\
\hline Life after death & 98 & 97 & 73 & 74 \\
\hline Heaven & 73 & 79 & 79 & 75 \\
\hline Hell & 75 & 79 & 69 & 62 \\
\hline (source: EVS 2015, 2017). & 41 & 64 & &
\end{tabular}

The great majority of members of Polish society approve of religious elements in the public sphere. Since the 1990s, relatively continuously, no more than 15 percent of Polish society declared themselves to be against Christian symbols in schools or public administration buildings, religious education in public schools, or even priests taking part in public ceremonies (Grabowska 2015). In addition, some new post-materialist cultural trends of late modernity that have arisen in the last few years in Poland show some correspondence with Catholicism. For instance, the recent emergence of moral sensibilities based mainly on empathy, kindness and the ethic of caring in Polish society could be labelled as 'invisible religion' (Pawlik 2017) and correspond to Pope Francis' documents and official teachings. Moreover, the emerging ecological values in Polish society find new support/reinforcement in official Polish Church initiatives (Sadowski 2020). 


\section{Catholicism in the Focus of Cultural Change}

For Demerath (2000, pp. 136-37), 'cultural Catholicism' denotes the manifestation of an eroded form of religion and 'the penultimate stage of religious secularization'. To some extent, strong manifestations of religious decline emerge in Poland after 1989. In 2015, no more than 35 percent declared that 'Poland today is a somewhat more religious country than it was in the 1970s and 1980s' (Pew Research Center 2017). Between 1991 and 2018, the proportion of people declaring themselves to be 'deeply religious' has increased slightly, from 10 to 11.1 percent. Meanwhile people's detachment from religion has increased considerably. The percentage of 'non-believers' has risen from 1.3 to 3 percent, the 'religiously indifferent' increased from 2.4 to 5.6 percent and those 'uncertain but attached to the religious tradition' has risen from 6 to 10.7 percent. Exactly 3.1 percent declare 'non-belonging to any religious group'. The increase in the percentages of strongly committed and non-religious people has resulted in the erosion of the group of Polish citizens in the middle ground who declare themselves to be merely 'believing'. This proportion has decreased from 79.9 to 69.6 percent over the last 27 years. This is not only a manifestation of the differentiation of religious attitudes of Poles, but also the process of religious polarization taking place in Poland, which means a stabilization or even a slight increase in the number of people with the highest level of religiosity, and a marked increase in non-religious people (Bieńkunska and Piasecki 2020).

People's affiliation with Catholicism is highly differentiated across the country. While in rural areas, 95.8 percent of respondents declare 'belonging to the Catholic Church', and only 0.7 percent 'not belonging to any religious group', in the biggest cities (those with more than half a million inhabitants) the percentages for religious affiliation are much lower, down to 79.3 percent for Catholics, and 11.5 percent for 'no religion'. Between 2016 and 2018, the percentage of Catholics in the largest cities in Poland decreased by almost 4 percentage points. In the countryside, 59.7 percent of respondents attend Holy Mass at least once a week, but in cities with more than 500,000 inhabitants, this figures is only 32.6 percent. Similarly, 65.9 percent of rural inhabitants declare their 'attachment to the parish or religious community' in contrast to 27.1 percent of city dwellers who declare not being attached. This contrast is evident in the comparison between rural areas and the biggest cities.

The attitude towards Catholicism also differs according to age. The growing religious polarization is found in the youngest generation (Grabowska and Gwiazda 2019). Poland is the leading country in the world in terms of the gap between the religiosity of younger persons (under 40) and older adults (aged 40 and above) (Pew Research Center 2018). Since at least 1988, members of the younger generation are convinced that their religiosity is declining (Sadlon 2020b). The highest proportion of those declaring 'no religion' (5.2 percent) is found in the youngest group of Polish citizens, those aged between 16 and 24 . On the other hand, 64.2 percent of the oldest generation (75 years and above) declare 'attending Holy Mass at least once a week', but for a younger group (25 to 34 years) no more than 36.1 percent do so. Since 2010, the proportion of students who declare their attendance at religious classes has been rapidly declining. In 2018, no more than 70 percent declared taking part in public religious education (Grabowska and Gwiazda 2019, pp. 162-65). Religious polarization includes not only the growing segment of non-religious persons but also the increasing share of dedicated religious persons in the Polish population, accompanied by the erosion of the proportion of those in the middle ground whose attitudes towards religion could be characterized as 'average'. The following statistics confirm this trend towards polarization. Since 1980, the percentage of Catholics regularly receiving Holy Communion during Sunday Mass has increased from only 7.8 to 17.3 percent in 2018 . In addition, the proportion of Catholics actively engaged in parish-based organizations has been growing. While in 1993, no more than four percent of Polish Catholics actively participated in such organizations, by 2013 this percentage had doubled to 8 percent and in 2018 it was 8.1 percent (Sadlon and Luiza 2020). This increasing social mobilization and self-organization of Polish Catholics reveals their growing agency. 
Another observable phenomenon is that the moral sensitivity of Poles has been transforming into more subjective, situationist and reflexive states. The institutional and normative background of moral judgements, including among members of the Catholic Church, has been declining. Nearly half of the population, 48 percent, claim that 'I do not feel any need to justify my morality by religion as my own conscience is enough'. This means that religious normativity transforms into 'multiple moralities' (Zigon 2011). In 2016, only 12 percent declared that 'only religion may justify moral imperatives', which was half the percentage obtained in 2009 (Boguszewski 2017a). In the same survey, the majority, 78 percent, claim that 'moral norms are independent of religious values' (Boguszewski 2017a). However, moral attitudes and religiosity are intertwined. Religious persons are more likely to declare negative attitudes towards abortion and sexual relationships outside religious marriage. Religious experience affects judgements concerning family and individual moral judgements, while it remains independent from the public moral sphere such as in professional work, during engagement in political activity or concerning attitudes towards democracy Boguszewski (2017b). When the link between politics and religion is surveyed, only general political party preferences are correlated to the level of religiosity (Szawiel 1996).

The percentage of people declaring themselves to be believers who respect the Church's rules decreased from 66 percent to 39 percent from 2005 to 2014 (Boguszewski 2017b). Religious change in Poland could be characterized not only as 'creeping secularization' (Mariański 2014) but also includes the declining moral role of the Catholic Church (Juros 1997), the weakening of the role of the Church and the reduction in the value of the Church's religious-symbolic forms of social integration (Mariański 2010, pp. 101-2; Gabriel 2008). Mariański (2014) argues that, since 2005, this process seems to have been accelerating considerably. (Table 2)

Table 2. Declared relationship to the Church in Poland (1990-2017) (in percent).

\begin{tabular}{lcccc}
\hline $\begin{array}{l}\text { Generally Speaking, My Church Is Giving } \\
\text { Adequate Answers to: }\end{array}$ & $\mathbf{1 9 9 0}$ & $\mathbf{1 9 9 9}$ & $\mathbf{2 0 0 8}$ & $\mathbf{2 0 1 7}$ \\
\hline $\mathrm{N}$ & 982 & 1095 & 1071 & 1167 \\
\hline \multicolumn{1}{c}{ In percent } & & & \\
\hline $\begin{array}{l}\text { The moral problems and needs of the } \\
\text { individual }\end{array}$ & 80 & 66 & 60 & 48 \\
\hline The problems of family life & 81 & 64 & 55 & 49 \\
\hline $\begin{array}{l}\text { People's spiritual needs } \\
\text { The social problems facing our country today }\end{array}$ & 89 & 83 & 78 & 71 \\
\hline source: EVS 2015, 2017) & 52 & 41 & 35 & 33 \\
\hline
\end{tabular}

(source: EVS 2015, 2017).

'De-churching' is observed not only in the individual religious but also in the public sphere. According to Jose Casanova (1994, p. 109), Catholicism in Poland was forced to face up to a new democratic order as the emerging civil society was divided between Catholicism and liberalism. As Piotr Gliński (2006, p. 31) highlights, the political process comprised the tendency to create a new civil society lacking 'a moral community' and saw the emergence of new intellectual elites who had no interest in grass-roots civil society. The strategy of integrating with the European Union and hence gaining access to European funds generated a process of separation between the 'old' Catholic civil society and the new liberal sector of civil organizations, as the definitions of civil society which were adopted actually excluded Catholic organizations. Such a liberal approach underestimated the role of Catholicism in shaping Polish civil society (Załęski 2012). 'Polish sociological research, especially surveys, neglected the role of civil activity rooted in religion and the Church, especially the role of parishes' (Gliński 2010, p. 5).

Since 1989, the growing public agency of Catholicism has clashed with 'strong liberal tendencies [which] have governed strategies for developing a civil society in Poland 
with such perspectives as autonomy, pluralism, distance from tradition, or even cultural eradication' (Sadlon 2020a, p. 177). Ireneusz Krzemiński highlights the strong change in the public role of Catholicism in his claim that, in contrast to the 1990s when Catholicism was associated with 'openness', in the subsequent decades it has come to represent instead a sort of 'repressive religiosity' that punishes and excludes (Krzemiński 2013, p. 450). This public role of religion accompanied the process of differentiation and pluralization within the Catholic socio-cultural system that resulted in the formation of segments of Polish Catholicism which were especially visible in the opposition between traditional listeners of Radio Maryja (a conservative Catholic radio station) on the one side and the more liberal readers of Tygodnik Powszechny (a liberal Catholic weekly magazine) on the other (Krzemiński 2017; Meyer Resende and Hennig 2021).

The growing negative assessment of the Church's activities may also give rise to negative actions, that, with reference to other countries of the region, may be labelled as the end of the 'pro-Catholic consensus' (Uzlaner 2018) or at a later stage, may even translate into a kind of 'anti-Catholicism'. In the late 1980s, almost 90 percent of Poles assessed the activities of the Catholic Church positively (Feliksiak 2019). This was undoubtedly due to the active participation of the Church in the social and political change which almost the entire society supported. Such an exceptionally positive assessment of the Catholic Church quickly broke down in the 1990s as, in fact, only part of Polish society approved of Catholic doctrine. Already in 1992, less than 50 percent of Poles assessed the Catholic Church positively as an outcome of public discussion on the public role of the Church, debate on the constitution of the Republic of Poland, the concordat, and the issue of financial compensation for the Church (Sadlon 2016). At the turn of the century, people's opinion of the Church improved somewhat. By 2010, about 65 percent of Poles assessed the Church positively. In 2010, when Polish politics were strongly affected by the airplane crash which killed the Polish President Lech Kaczynski, his wife, and 96 public figures who were on board, trust in the Church dropped significantly, to 50 percent, and declined year by year thereafter. In 2011, a strong anti-Catholic campaign was inaugurated mainly by political forces, and the anticlerical and antireligious party Ruch Palikota (Palikot's Movement) gained about 10 percent of the vote in the parliamentary election of 2011. Janusz Palikot was a Polish activist, politician and businessman who organized happenings, demonstrations, as well as political campaigns. In 2018 and 2019, negative attitudes towards the Church were strengthened by sexual abuse scandals involving the clergy (Feliksiak 2019). Recent studies indicate that we are dealing with another increase in negative opinions of the Church.

Discussion of modern political conflicts in Poland refer to Catholicism as an element and the fact that political attitudes in Poland has been increasingly correlated with religious attitudes (Rosta 2014). Liberal left-wing circles instrumentalised Pope Francis' appeal to the Church to welcome immigrants. Paradoxically, such appeals to the authority of the Church have become a pretext for religious argument and in fact have sanctioned the separation of state and Church (Gierycz 2016). Aspects of religiosity interfere with political preferences. Attachment to the Church's model of religiosity, which means not only its religious practices but also the acceptance of its moral teachings, corresponds with more conservative political preferences, but not extreme right-wing views. Polish citizens who live rather individualized lives, not in accordance with Catholic forms of religiosity, tend to prefer left-wing or centrist political inclinations (Grabowska 2015).

A contributing factor of growing significance to political polarization in Poland has been gender (Szwed and Zielińska 2017), especially the important ethical issue of abortion. Until 1989, Poland had a very permissive law on abortion. In 1956, the Communist Parliament legalised abortion in cases where the woman was experiencing 'difficult living conditions' (Dziennik Ustaw 1956). Research conducted in 1958, two years after the legalization of abortion in Poland, demonstrated that religiosity did not affect attitudes towards abortion to the extent that is observed in contemporary Polish society. Persons who declared themselves to be 'believing and regularly practicing' claimed that legislation 
on abortion (without limitations) was needed; 11.6 percent claimed it was 'very necessary' and 31.2 percent, 'necessary' (Malanowski 1960). The transition to democracy initiated an emotional public debate on the moral limits of abortion and resulted in new legislation passed by the Polish Parliament in 1993. According to the new law, abortions could be legally obtained only in cases of serious threat to the life or health of the woman, cases of rape or incest and when the foetus was seriously and irreversibly damaged. In 1996, the Polish Parliament legalized abortion due to 'the social situation of the woman' (Dziennik Ustaw 1996) but in the following year the Constitutional Tribunal (Trybunał Konstytucyjny 1997) adjudicated this change as not in compliance with the Polish Constitution. In the 2010s, pro-life organizations collected over 500,000 signatures for a proposed bill to ban abortion altogether. The Catholic Church in Poland has been vocal in this debate on abortion. John Paul II, during his visits to Poland in the 1990s and in his 1995 encyclical Humane Vitae, insisted on the saving of human life (Grześkowiak 2017). According to polls conducted since the 1990s, restrictive attitudes towards abortion have been growing in Polish society, until the so-called "Black Protests" of 2016, after which the proportion supporters to abortion has slightly increased (Feliksiak and Rogulska 2020). In 2020, a constitutional tribunal in Poland ruled that abortions for fetal abnormalities violate the country's Constitution. The Protests were organized across the entire country, despite pandemic restrictions.

An understanding of the role of the debate on abortion must also include an examination of the impact of religiosity on people's discriminating moral assessment of abortion. The crucial issue here for the topic of this article is the fact that religiosity strongly counteracts the moral justification for abortion in Polish society. In 2020, as presented in Table 3, less than 44 percent of those regularly practicing (at least one a week) Polish citizens affirmed that abortion should be legal in the case of 'child's disability' and 10 percent in the case of 'mother's difficult financial situation'. The level of religiosity has a high correlation with a negative attitude towards abortion.

Table 3. Assessment of abortion according to declared religious practices in 2020.

\begin{tabular}{|c|c|c|c|c|c|c|c|}
\hline \multirow{2}{*}{\multicolumn{2}{|c|}{ Assessment of Abortion }} & \multicolumn{6}{|c|}{ Declared Attendance at Religious Service } \\
\hline & & \multirow{2}{*}{$\begin{array}{c}\text { Total } \\
86\end{array}$} & \multirow{2}{*}{$\begin{array}{c}\begin{array}{c}\text { Several Times a } \\
\text { Week }\end{array} \\
50\end{array}$} & \multirow{2}{*}{$\begin{array}{c}\text { Once a Week } \\
80\end{array}$} & \multirow{2}{*}{$\begin{array}{c}\begin{array}{c}\text { 1-2 Times } \\
\text { a Week }\end{array} \\
91\end{array}$} & \multirow{2}{*}{$\begin{array}{c}\begin{array}{c}\text { Several Times } \\
\text { a Year }\end{array} \\
93\end{array}$} & \multirow{2}{*}{$\frac{\text { Not at Al }}{94}$} \\
\hline Ahortion should be & Yes & & & & & & \\
\hline legal if mother's life & No & 8 & 42 & 11 & 5 & 4 & 3 \\
\hline is at risk & Hard to say & 6 & 8 & 10 & 4 & 3 & 3 \\
\hline \multirow{3}{*}{$\begin{array}{l}\text { Abortion should be } \\
\text { legal if mother's } \\
\text { health is at risk }\end{array}$} & Yes & 79 & 38 & 67 & 85 & 90 & 91 \\
\hline & No & 13 & 46 & 20 & 8 & 4 & 5 \\
\hline & Hard to say & 8 & 15 & 13 & 7 & 6 & 4 \\
\hline \multirow{3}{*}{$\begin{array}{l}\text { Abortion should be } \\
\text { legal in case of rape } \\
\text { or incest }\end{array}$} & Yes & 79 & 38 & 67 & 92 & 89 & 89 \\
\hline & No & 12 & 44 & 19 & 5 & 6 & 5 \\
\hline & Hard to say & 9 & 18 & 14 & 3 & 6 & 5 \\
\hline \multirow{3}{*}{$\begin{array}{l}\text { Abortion should be } \\
\text { legal in case of } \\
\text { child's disability }\end{array}$} & Yes & 64 & 21 & 44 & 75 & 80 & 82 \\
\hline & No & 22 & 64 & 38 & 15 & 10 & 7 \\
\hline & Hard to say & 14 & 14 & 19 & 10 & 9 & 11 \\
\hline \multirow{3}{*}{$\begin{array}{l}\text { Abortion should be } \\
\text { legal in case of } \\
\text { mother's difficult } \\
\text { financial situation }\end{array}$} & Yes & 20 & 5 & 10 & 19 & 27 & 34 \\
\hline & No & 69 & 91 & 82 & 71 & 63 & 52 \\
\hline & Hard to say & 11 & 4 & 9 & 10 & 10 & 14 \\
\hline \multirow{3}{*}{$\begin{array}{l}\text { Abortion should be } \\
\text { legal in case mother } \\
\text { just does not want to } \\
\text { have a child }\end{array}$} & Yes & 18 & 5 & 8 & 16 & 23 & 32 \\
\hline & No & 73 & 93 & 84 & 75 & 68 & 56 \\
\hline & Hard to say & 9 & 2 & 8 & 9 & 9 & 12 \\
\hline
\end{tabular}




\section{Conclusions}

Polish Catholicism entered the Polish political and social transformation process to some extent as an agential force which shaped progressive social change and delivered 'energy' for the transformation. This public role of Polish Catholicism was strongly embedded in popular religiosity and pastoral activities in local communities, as well as in patriotic attitudes. The recent role of Catholicism in modern Polish society was delineated in the transition from Communism and has been strongly and actively conditioned by collective agency. Religious ideas and beliefs, as components accumulated within traditional Polish culture, have causally influenced the socio-cultural context of the society. Despite the policy pursued by the Polish People's Republic in the 1950s, 1960s and 1970s, which aimed at excluding the Church from society, subsequently, together with the Solidarity movement and the inspirational grassroots transformations of the 1980s, the Catholic Church has become a symbol of freedom and an inspiration for systemic change. This has greatly enhanced the historic bond between Catholicism, national identity and patriotism and renewed the symbolic role of the Church in shaping the national community. The Church, in its basic function of evangelization, stood in defence of democracy and human rights (Borowik 2002), which led to the presence of the Catholic Church in the political sphere (Jasiukiewicz 1993). Catholicism was allied with the struggle for freedom and national identity. The political role of Catholicism represents strong continuity with this agential force.

However, the process of transformation has changed the public situation of the Catholic Church. Catholicism is no more an actor within the dominant former social movement that thrived on the call to freedom and human rights. As a result of new socialization patterns and the growing pluralism within Polish Catholicism, its public role has changed dramatically during the last three decades. In addition, as the result of its dynamic institutionalization after 1989, the Catholic Church has begun to represent a public institution and a socio-cultural system of power. In recent decades, trust in the Catholic Church has started to decline just as the political landscape is being shaped by growing political confrontation and pluralism.

However, just as a growing pluralism characterizes not only Polish Catholicism but also the whole of Polish society, my conclusion is that Catholicism in Poland still represents a crucial cultural system that conditions the whole of the Polish socio-cultural system. Until today there is no alternative system of meaning, beliefs or ideas that could compete in inspiring the relatively vast and considerable collective activity which is contemporary Polish society.

The impact of Catholicism upon the Polish nation should not be reduced to an authoritative structure of power. On the contrary, Catholicism still represents a symbolic and agential complex of attitudes, values, and identities, rather than institutions and organizations that affect political life directly. Following the theoretical distinction between cultural and socio-cultural system outlined in the introduction, Catholicism still represents a cultural system that affects the Polish socio-cultural system. In the public sphere, Catholicism in Poland plays a role in shaping the social attitudes and values of part of Polish society and contributes to politics as a symbolic system which still represents a frame of reference for the moral system of Polish society.

Catholicism, as an aspect of Polish society which plays a role in shaping social antagonisms and conflicts, still represents to some degree 'a public good'. That is why, despite strong political polarization in Poland, there are no circumstances for applying the concept of 'pillarization' within Polish society. The situation of Catholicism in the modern Polish social configuration should be described using the category of polarization rather than pillarization (Tworzecki 2019). My study of Polish Catholicism confirms that social polarization in Poland is not a bottom-up process but rather is driven from the top down as a cultural process.

Nowadays two possible perspectives on Polish Catholicism-both a structural and an agential point of view-should be taken into account to understand the role of Catholicism in Polish society including its politics. The conditioning of the Polish socio-cultural system 
by Catholic norms results from both an agential and a structural configuration of the relationship between Catholicism and Polish society. Catholicism represents a system of values and beliefs that shapes individual and social identities and emerges as collective activity. The public and political agential role of Catholicism results from the fact that Catholicism represents a more expansive and extensive socio-cultural system than any other alternative socio-cultural system that could compete with it in Poland.

Funding: This research received no external funding.

Institutional Review Board Statement: Not applicable.

Informed Consent Statement: Not applicable.

Data Availability Statement: www.iskk.pl (accessed on 18 June 2021).

Conflicts of Interest: The authors declare no conflict of interest.

\section{Note}

Depending on considering or not considering missing data.

\section{References}

Adamski, Franciszek. 1986. Rodzina Między Sacrum i Profanum. Poznań: Pallottinum.

Altermatt, Urs. 1980. Katholische Subgesellschaft. Thesen zum Konzept der 'katholischen Subgesellschaft' am Beispiel des Schweizer Katholizismus. In Zur Soziologie des Katholizismus. Edited by Karl Gabriel and Franz-Xaver Kaufmann. Mainz: Grünewald, pp. 145-65.

Archer, Margaret Scotford. 1988. Culture and Agency. The Place of Culture in Social Theory. Cambridge: Cambridge University Press.

Archer, Margaret Scotford. 1995. Realist Social Theory. Cambridge: Cambridge University Press.

Archer, Margaret Scotford. 2000. Being Human: The Problem of Agency. Cambridge: Cambridge University Press. [CrossRef]

Bieńkunska, Anna, and Tomasz Piasecki. 2020. Religijność a dobrobyt subiektywny na podstawie Badania spójności społecznej 2018 r. [Religiosity and subjective well-being on the basis of the Social Cohesion Survey 2018]. In Wyznania Religijne w Polsce $2015-2018$ [Religious Denominations in Poland 2015-2018]. Edited by Paweł Ciecielag. Warszawa: Główny Urzad Statystyczny, pp. 359-71.

Billiet, Jaak, and Karel Dobbelaere. 1976. Godsdienst in Vlaanderen. Leuven: Davidsfonds.

Boguszewski, Rafał. 2017a. Komunikat z Badan: Zasady Moralne a Religia [Moral Values and Religion]. Warszawa: Centrum Badania Opinii Publicznej.

Boguszewski, Rafał. 2017b. Komunikat z Badan: Etyka Pracownicza [Employee Ethics]. Warszawa: Centrum Badania Opinii Publicznej.

Boguszewski, Rafał. 2018. Pamiec o Janie Pawle II ciagle zywa. Warszawa: Centrum Badania Opinii Publicznej.

Borowik, Irena. 2002. The Roman Catholic Church in the Process of Democratic Transformation: The Case of Poland. Social Compass 49: 239-52. [CrossRef]

Borowski, Karol. 1985. The Sociology of Religion in Modern Poland: A Critical Review. Sociological Analysis 46: 389-99. [CrossRef]

Casanova, Jose. 1994. Public Religion in The Modern World. Chicago: University of Chicago Press.

Ciecielag, Paweł, and Paweł Boryszewski. 2017. Zaangazowanie religijne [Religious Engagement]. In Jakosc zycia w Polsce w 2015 r. Wyniki badania spojnosci spolecznej [Quality of Life in Poland 2015. Results of a Social Cohesion Survey]. Edited by A. Bienkunska and T. Piasecki. Warszawa: Glowny Urzad Statystyczny, pp. 113-42.

Cohen, Jean L., and Andrew Arato. 1994. Civil Society and Political Theory. London and Cambridge: MIT Press.

Damberg, Wilhelm. 1997. Abschied vom Milieu? Katholizismus im Bistum Munster und in den Niederlanden, 1945-1980. Paderborn: F. Schoningh.

Demerath, Nicholas. 2000. The Rise of "Cultural Religion" in European Christianity: Learning from Poland. Northern Ireland. and Sweden. Social Compass 47: 127-39. [CrossRef]

De Certeau, Michel. 1966. Culture and Spiritual Experience. Concilium 9: 3-16.

Diamanti, Ilvo, and Luigi Ceccarini. 2007. Catholics and politics after the Christian democrats: The influential minority. Journal of Modern Italian Studies 12: 37-59. [CrossRef]

Dmochowska, Małgorzata. 2012. Nowe wspólnoty w Polsce na przełomie XX i XXI wieku. Między Platonem, Amwayem a Trollami. Warszawa: Wydawnictwo IFiS PAN.

Dyczewski, Leon. 1980. System wartości w świadomości młodego pokolenia. Roczniki Nauk Społecznych 8: $259-71$.

Dziennik Ustaw. 1956. 1956 nr 12 poz. 61, Ustawa z dnia 27 kwietnia 1956 r. o warunkach dopuszczalności przerywania ciąży. Available online: http:/ /isap.sejm.gov.pl/isap.nsf/DocDetails.xsp?id=wdu19560120061 (accessed on 18 June 2021).

Dziennik Ustaw. 1989. Ustawa z dnia 17 maja 1989 r. o gwarancjach wolności sumienia i wyznania, Dziennik Ustaw, 1989 nr 29 poz. 155. Available online: https://isap.sejm.gov.pl/isap.nsf/DocDetails.xsp?id=WDU19890290155 (accessed on 18 June 2021). 
Dziennik Ustaw. 1996. 1996 nr 139 poz. 646, Ustawa z dnia 30 sierpnia 1996 r. o zmianie ustawy o planowaniu rodziny, ochronie płodu ludzkiego i warunkach dopuszczalności przerywania ciąży oraz o zmianie niektórych innych ustaw. Available online: https:/ /isap.sejm.gov.pl/isap.nsf/DocDetails.xsp?id=WDU19961390646 (accessed on 18 June 2021).

Dziennik Ustaw. 2003. Ustawa o Działalności Pożytku Publicznego i Wolontariacie, Dziennik Ustaw, 2003 nr 96 poz. 873 , par. 3. pkt.3. Available online: http:/ /isap.sejm.gov.pl/isap.nsf/DocDetails.xsp?id=wdu20030960873 (accessed on 18 June 2021).

Eberts, Mirella. 1998. The Roman Catholic Church and Democracy in Poland. Europe-Asia Studies 50: 817-42. [CrossRef]

EVS. 2015. European Values Study 1981-2008: Longitudinal Data File 1981-2008. Cologne: GESIS Data Archive. [CrossRef]

EVS. 2017. European Values Study 2017: Integrated Dataset 2017. Cologne: GESIS Data Archive. [CrossRef]

Feliksiak, Michał. 2019. Oceny Działalności Parlamentu, Prezydenta. PKW i Kościoła rzymskokatolickiego. Warszawa: Centrum Badania Opinii Publicznej.

Feliksiak, Michał, and Beata Rogulska. 2020. O Dopuszczalności Przerywania Ciąży i Protestach po Wyroku Trybunału. Konstytucyjnego: Warszawa: Centrum Badania Opinii Publicznej.

Gabriel, Karl. 2008. Zwischen Entkirchlichung. Individualisierung und Deprivatisierung: Institutionalisierte Religiositaet in Europa. In Religioese Ueberzeugungen und oeffentliche Vernunft. Zur Rolle des Christentums in der pluralistischen Gesellschaft. Edited by B. Irlenborn and F.-J. Bormann. Freiburg im Breisgau: Herder, pp. 45-60.

Gawin, Dariusz. 2013. Wielki Zwrot. Ewolucja Lewicy i Odrodzenie Idei Społeczeństwa Obywatelskiego 1956-1976. Kraków: Znak.

Gierycz, Michał. 2016. Polska debata o imigracji w perspektywie politologii religii. Chrześcijaństwo-Świat-Polityka 20: 73-84. [CrossRef]

Gliński, Piotr. 2006. Style Działań Organizacji Pozarzadowych w Polsce. Grupy Interesu czy Pożytku Publicznego? Warszawa: Wyd. IFiS PAN, p. 31.

Gliński, Piotr. 2010. Obywatele rodzą się (też) w Kościele. Więź 7: 5.

Głowacki, Antoni. 2018. Komunikat z badan: Wielkanoc 2018. Warszawa: Centrum Badania Opinii Publicznej.

Grabowska, Mirosława. 2015. Boskie i Cesarskie. O stosunkach Między Państwem i Kościołem(ami). Konstytucyjnego: Komunikat CBOS, p. 48.

Grabowska, Mirosława, and Magdalena Gwiazda. 2019. Mlodziez 2018. Warszawa: Centrum Badania Opinii Publicznej.

Greeley, Andrew. 1962. Some aspects of interaction between religious groups in an upper middle class Roman Catholic parish. Social Compass 9: 39-61. [CrossRef]

Grześkowiak, Alicja. 2017. Ochrona życia w nauczaniu Jana Pawła II. Studia Prawnicze KUL 4: 125-76. [CrossRef]

Grzymała-Busse, Anna. 2015. Nations under God: How Churches Use Moral Authority to Influence Policy. Princeton: Princeton University Press.

Gudaszewski, Grzegorz. 2015. Struktura narodowo-etniczna, jezykowa i wyznaniowa ludnosci Polski. Narodowy Spis Powszechny Ludnosci i Mieszkan 2011. Warszawa: Główny Urząd Statystyczny.

Habermas, Jurgen. 1987. Theory of Communicative Action, Volume Two: Lifeworld and System: A Critique of Functionalist Reason. Boston: Beacon Press. First published 1981.

Hellemans, Staf. 2020. Pillarization ('Verzuiling'). On Organized 'Self-Contained Worlds' in the Modern World. The American Sociologist 51: 124-47. [CrossRef]

Herberg, Will. 1955. Protestant_Catholic_Jew. An Essay in American Religious Sociology. Garden City: Doubleday.

Hipsz, Natalia. 2013. Komunikat z badan: Spoleczne oceny alternatyw zycia malzenskiego. Warszawa: Centrum Badania Opinii Publicznej.

Hruby, Suzanne. 1982. The Church in Poland And Its Political Influence. Journal of International Affairs 36: 317-28, JSTOR. Available online: www.jstor.org/stable/24356444 (accessed on 14 December 2020).

Inglehart, Ronald, and Wayne E. Baker. 2000. Modernization, cultural change, and the persistence of traditional values. American Sociological Review 49: 19-51. [CrossRef]

Jaroń, J. 2014. Szkolnictwo katolickie i nauka religii [Catholic Schools and Religious Education]. In Kosciol Katolicki w Polsce 1991-2011. Rocznik statystyczny [Catholic Church in Poland 1991-2011. Statistical Yearbook]. Edited by Paweł Ciecielag, Wojciech Sadlon and iotr Łyson. Warszawa: Instytut Statystyki Koscioła Katolickiego and Glowny Urzad Statystyczny, pp. 231-34.

Juros, Helmut. 1997. Kościót. kultura. Europa. Katolicka nauka społeczna wobec wspótczesności. Lublin-Warszawa: Fundacja ATK.

Jasiukiewicz, Marian. 1993. Kościót Katolicki w polskim życiu Politycznym 1945-1989: Podstawowe Uwarunkowania [The Catholic Church in Polish Public Life 1945-1989]. Prace Naukowe Akademii Ekonomicznej we Wrocławiu.. Seria: Monografie i Opracowania, vol. 649, pp. 1-200.

Jewdokimow, Marcin, and Sadlon Wojciech. 2020. Rozprawa habilitacyjna Witolda Zdaniewicza z perspektywy pół wieku. In System społeczny zakonu a funkcja apostolska (na przykładzie żeńskich zgromadzeń zakonnych w Polsce). Edited by W. Zdaniewicz. Warszawa: Wydawnictwo Naukowe Uniwersytetu Kardynała Stefana Wyszyńskiego.

Köllner, Tobias. 2016. Patriotism, Orthodox religion and education: Empirical findings from contemporary Russia. Religion, State and Society 44: 366-86. [CrossRef]

Koseła, Krzysztof. 2003. Polak-Katolik. Splatana Tozsamosc. Warszawa: Instytut Filozofii i Socjologii Polskiej Akademii Nauki.

Kruijt, Jakob Pieter, and Walter Goddijn. 1962. Verzuiling en ontzuiling als sociologisch proces. In Drift en Koers. Een Halve Eeuw Sociale Verandering in Nederland. Edited by Arie Nicolaas Jan den Hollander. Van Gorcum: Assen, pp. 227-63.

Krzemiński, Ireneusz. 2013. Solidarność. Niespetniony Projekt Polskiej Demokracji. Gdańsk: Uropejskie Centrum Solidarności, p. 450. 
Krzemiński, Ireneusz. 2017. Radio Maryja and Fr. Rydzyk as a Creator of the National-Catholic Ideology. In Religion, Politics, and Values in Poland. Palgrave Studies in Religion, Politics, and Policy. Edited by S. Ramet and I. Borowik. New York: Palgrave Macmillan. [CrossRef]

Leszczyńska, Katarzyna. 2016. Płeć w instytucje uwikłana: Reprodukowanie wzorców kobiecości i męskości przez świeckie kobiety i świeckich mężczyzn w organizacjach administracyjno-ewangelizacyjnych Kościoła rzymskokatolickiego w Polsce. Warszawa: Scholar.

Liedhagener, Anotniu. 2018. Pluralizirung, Detlef Pollack, Volkhard Krech, Olaf Müller, Markus Hero Hrsg, Handbuch Religionssoziologie. Berlin/Heidelberg: Springer, pp. 347-82.

Majka, Józef. 1980. Uwarunkowania Katolicyzmu Polskiego [The Context of Polish Catholicism]. Chrześcijanin w Świecie. Zeszyty ODiSS. Warszawa: ODISS, vol. 94, pp. 27-44.

Malanowski, Jan. 1960. Stosunek Społeczeństwa do Przyrostu Naturalnego, Ośrodek Badania Opinii Publicznej przy. Warszawa: Polskim Radio.

Mariański, Janusz. 2010. Religia w spoleczenstwie ponowoczesnym. Studium socjologiczne. Warszawa: Oficyna Naukowa.

Mariański, Janusz. 2014. Entwicklungstendenzen der katholischen Religiosität in Polen. In Zwischen Säkularisierung und religiöser Vitalisierung. Veröffentlichungen der Sektion Religionssoziologie der Deutschen Gesellschaft für Soziologie. Edited by Michael, Hainz, Gert, Pickel, Detleff, Pollack, Maria Libiszowska-Żóttkowska and Elżbieta Firlit. Wiesbaden: Springer. [CrossRef]

Meyer Resende, Madalena, and Anja Hennig. 2021. Polish Catholic Bishops, Nationalism and Liberal Democracy. Religions 12: 94. [CrossRef]

Michel, Patrick. 1988. La Société Retrouvée. Politique et Religion dans l'Europe soviétisée. Paris: Fayard.

Morawska, Ewa. 1984. Civil Religion Versus State Power in Poland. Society 21: 29-34. [CrossRef]

Pawlik, Wojciech. 2017. Visible Religion, Invisible Ethics. In Religion, Politics, and Values in Poland. Palgrave Studies in Religion, Politics, and Policy. Edited by Sabrina Ramet and Irena Borowik. New York: Palgrave Macmillan. [CrossRef]

Pew Research Center. 2017. Religious Belief and National Belonging in Central and Eastern Europe. National and religious identities converge in a region once dominated by atheist regimes. [online]. Available online: https:/ / www.pewforum.org/2017/05/10/religious-beliefand-national-belonging-in-central-and-eastern-europe/ (accessed on 18 June 2020).

Pew Research Center. 2018. The Age Gap in Religion Around the World. [online]. Available online: https://www.pewforum.org/2018/0 6/13/the-age-gap-in-religion-around-the-world/ (accessed on 18 June 2020).

Polish Statistics. 2020. Sektor Non-Profit w 2018. Warszawa: Polish Statistics.

Poulat, Emile. 1986. L'Eglise, c'est un monde. Paris: Cerf.

Rojek, Paweł. 2011. Mesjanizm integralny. Pressje 26: 20-49.

Rojek, Paweł. 2016. Mesjanizm Solidarności: Religia, naród i reformy w latach osiemdziesiatych. Krakó: Wydawnictwo M.

Rosta, Gergley. 2014. Religiosität und politische Präferenzen-Polen und Deutschland. In Zwischen Säkularisierung und religiöser Vitalisierung. Edited by Michael Hainz. Wiesbaden: Religiosität in Deutschland und Polen im Vergleich, pp. 135-46.

Sadlon, Wojciech. 2014. Religijny kapitał społeczny: Kapitał społeczny a Kościót katolicki w społecznościach lokalnych w Polsce. Saarbrücken: Wydawnictwo Bezkresy Wiedzy.

Sadlon, Wojciech. 2015. Społeczne przejawy ludzkiej wolności-Religia i społeczeństwo obywatelskie. Kwartalnik Trzeci Sektor 34: $11-18$.

Sadlon, Wojciech. 2016. Zwischen Volksreligiosität und Gemeinnütziger Tätigkeit. Die Aktuelle Diskussion um die Finanzierung der Kirche in Polen. In Geld, Gott und Glaubwürdigkeit, Ferdinand Schöningh Verlag. Edited by Karl Abmeier. Paderborn: Verlag Ferdinand Schöningh, pp. 155-64. [CrossRef]

Sadlon, Wojciech. 2019. Ciagłość i zmiana wiejskich parafii katolickich. In Ciagłość i zmiana. Sto lat rozwoju polskiej wsi. Tom 1. Edited by Maria Halamska, Monika Stany and Jerzy Wilkin. Warszawa: Instytut Rozwoju Wsi i Rolnictwa PAN, pp. 351-87.

Sadlon, Wojciech. 2020a. Civil Cinderella. Religion and Civil Society in Poland. In Religious Communities and Civil Society in Europe, 1st ed. Edited by Rupert Graf Strachwitz. Berlin: De Gruyter, pp. 149-82. [CrossRef]

Sadlon, Wojciech. 2020b. Students' religiosity in their own assessment. In Between Construction and Deconstruction of the Universes of Meaning. Research into the Religiosity of Academic Youth in the Years 1988-1998-2005-2017. Edited by S. Zareba and M. Zarzecki. Berlin: Peter Lang, pp. 125-46. [CrossRef]

Sadlon, Wojciech. 2021. Polish Catholicism Between Tradition and Migration. Agency, Reflexivity, Transcendence. Abington: Routledge.

Sadlon, Wojciech, and Organek Luiza. 2020. Annuarium Statisticum Ecclesiae in Polonia. Warszawa: Institut Statystyki Kościoła Katolickiego, Available online: http://iskk.pl/images/stories/Instytut/dokumenty/Annuarium_Statisticum_DANE_2019 _FINAL_KOREKTA_26012021.pdf (accessed on 18 June 2021).

Sadowski, Ryszard. 2020. The Role of Religious Argumentation in Shaping Pro-ecological Attitudes of Christians in Poland. Studia Ecologiae et Bioethicae 18: 7-22. [CrossRef]

Schöpflin, George. 1974. Poland: Troubled relations between church and state. Religion in Communist Lands 2: 4-7. [CrossRef]

Seligmann, Adam. 1992. Idea of Civil Society. New York: Simon and Schuster.

Sokołowski, Wojciech. 2006. Civil Society and the Professions in Eastern Europe: Social Change and Organizational Innovation in Poland. Berlin and Heidelber: Springer Science \& Business Media. 
Szawiel, Tadeusz. 1996. Postawy i orientacje społeczne polskich katolikow w trzy lata po rozpoczęciu reform politycznych i ekonomicznych [Attitudes and Social Orientations of Polish Catholics Three Years After Political and Economic Reforms]. In Od Kościoła ludu do kościoła wyboru. Religia i przemiany społeczne w Polsce. Edited by Irena Borowik and Witold Zdaniewicz. Krakow: Zaklad Wydawniczy Nomos, pp. 49-95.

Sztompka, Piotr. 2007. Zaufanie. Fundament społeczeństwa. Kraków: Znak.

Szwed, Anna, and Katarzyna Zielińska. 2017. A War on Gender? The Roman Catholic Church's Discourse on Gender in Poland. In Religion, Politics, and Values in Poland. Palgrave Studies in Religion, Politics, and Policy. Edited by Sabrina Ramet and Irena Borowik. New York: Palgrave Macmillan. [CrossRef]

Taylor, Charles. 1989. Sources of the Self. The Making of the Modern Identity. Cambridge: Harvard University Press.

Trybunał Konstytucyjny. 1997. Obwieszczenie Prezesa z dnia 18 grudnia 1997 r. o utracie mocy obowiązujacej art. 1 pkt 2, art. 1 pkt 5 , art. 2 pkt 2, art. 3 pkt 1 i art. 3 pkt 4 ustawy o zmianie ustawy o planowaniu rodziny, ochronie płodu ludzkiego i warunkach dopuszczalności przerywania ciąży oraz o zmianie niektórych innych ustaw, Dziennik Ustaw 1997 nr 157 poz. 1040 . Available online: http:/ / isap.sejm.gov.pl/isap.nsf/DocDetails.xsp?id=WDU19971571040 (accessed on 18 June 2020).

Turner, Bryan, and Rosario Forlenza. 2020. Max Weber and the Late Modernization of Catholicism. In The Oxford Handbook of Max Weber. Edited by Edith Hanke, Lawrence Scaff and Sam Whimster. Oxford: Oxford University Press. [CrossRef]

Tworzecki, Hubert. 2019. Poland: A Case of Top-Down Polarization. Pennsylvania: ANNALS, AAPSS, p. 681. [CrossRef]

Uzlaner, Dmitry. 2018. The End of the Pro-Orthodox Consensus: Religion as a New Cleavage in Russian Society. In Orthodox Religion and Politics in Contemporary Eastern Europe: On Multiple Secularisms and Entanglements. Edited by Koellner Tobias. London and New York: Routledge, pp. 173-92.

Wódka, Marek. 2017. Social and Economic Significance of Moral Capital. Annales. Etyka W Życiu Gospodarczym 20: 65-75. [CrossRef]

Załęski, Paweł. 2012. Neoliberalizm i Społeczeństwo Obywatelskie. Torun: Fundacja Nauki Polskiej.

Zarzecki, Marcin. 2015. Civil Religion. The Religion Of The Republic. The Religion Of Democracy. Social Religion I A Common Faith. Jako Kategorie Analityczne Socjologii Religii. Konteksty Społeczne 3: 93-108.

Witold, Zdaniewicz, and Sadlon Wojciech, eds. 2011. Spis Duchowieństwa Diecezjalnego oraz Członków Instytutów Życia Konsekrowanego i Stowarzyszeń Życia Apostolskiego. Warszawa: Instytut Statystyki Kościoła Katolickiego.

Zielińska, Katarzyna. 2011. Localising secularisation thesis? The view from Poland. Religion and Society in Central and Eastern Europe 4: 79-91.

Zielińska, Katarzyna. 2018. W Walce o Hegemonię? Religia w Polskiej Sferze Publicznej na Przykładzie Debat Sejmowych. Kraków: Wydawnictwo Uniwersytetu Jagiellońskiego.

Zigon, Jarrett. 2011. Multiple Moralities and Religion in the Post-Soviet Russia. New York: Berghahn Books.

Zubrzycki, Genvieve. 2006. The Crosses of Auschwitz. Nationalism and Religion in Post-Communist Poland. Chicago and London: Chicago University Press.

Żurek, J. 1996. Polityka Oswiatowa Panstwa Wobec Kosciola Katolickiego w Polsce w Latach 1961-1976. Warszawa: Manusript. 